\title{
Trade +
}

\section{Introduction}

\section{Marie-Bénédicte Dembour and Neil Stammers}

While Free Trade Agreements (FTAs) and Bilateral Investment Treaties (BITs) have a long history, a new generation of 'trade-plus' agreements has surfaced only relatively recently. Alternatively described as 'comprehensive', 'mega', or 'mega-regional', these agreements are distinctive insofar as they seek to combine traditional issues about trade in goods and services with many other aspects of economic activity such as investment, intellectual property rights, procurement, competition and regulatory harmonisation. Where they are heading, however, has become very uncertain even though they have hardly been born.

A leap of imagination is required to remember that, when the European Union started negotiating a 'trade-plus' agreement with the United States in 2013, few doubted that this would result in a legally binding agreement called the Transatlantic Trade and Investment Partnership (TTIP). Yet many now believe TTIP will never be signed. ${ }^{1}$ A second such agreement, the Comprehensive Economic and Trade Agreement (CETA) between the EU and Canada fared better. It was signed in October 2016-but not without trouble. The Walloon Parliament of Belgium refused to endorse CETA just as Canadian Prime Minister Justin Trudeau was preparing to come to Brussels for the signing ceremony. Wallonia's agreement was obtained on condition that the Belgian government referred the treaty's Investment Court System (ICS) to the Court of Justice of the European Union for their opinion on its

\footnotetext{
${ }^{1}$ In August 2016 the French Trade Minister is reported to have said 'These negotiations are dead and France wants an end to them... $\mathrm{t}$ ] here is no political support in France for these negotiations." http://www.telegraph.co.uk/business/2016/08/30/hollande-casts-doubt-on-eu-us-trade-deal-as-french-tradeministe/ (last visited 5 February 2018). Following speculation that the EU was hoping for an early resumption of talks, any such hopes were dashed in the summer of 2017 when Brussels sources were reported as saying that 'The prospect of a revived EU-US trade deal is in "deep freeze"'. https://www.theguardian.com/business/2017/jun/05/hopes-of-eu-us-trade-agreement-put-on-ice-saybrussels-sources (last visited 5 February 2018).
} 
compatibility with EU law. This referral was made in September $2017 .^{2}$ It is worth noting that ICS was itself a concession won after opposition had mounted against the InvestorState Dispute Settlement (ISDS) system which has been at the core of international investment law since the mid-twentieth century and had originally been intended to be adopted in both CETA and TTIP. ${ }^{3}$ Partly because of ISDS (but also because of other issues which had grabbed public attention) an unprecedented three million citizens had asked the European Commission to stop negotiating TTIP in autumn 2015. ${ }^{4}$ In Germany, judges released a critical statement on ISDS. ${ }^{5}$ This led the EU and Canada to agree to create an Investment Court System in CETA, which they claimed represented a clean break with the previous system, ${ }^{6}$ though it failed to satisfy their sterner critics.

Further afield, twelve parties, including the United States, Japan, Canada, Australia and a string of other Pacific countries, signed the Trans-Pacific Partnership (TPP) in February 2016. The original intent and impact of the TPP appeared seriously compromised after Donald Trump withdrew the USA from the agreement in February 2017. The remaining eleven members nonetheless announced agreement on the core elements of a Comprehensive and Progressive Agreement for Trans-Pacific Partnership (CPTPP) in November 2017. ${ }^{7}$ Moreover, a month later, the EU and Japan announced that they had agreed the terms of a free trade agreement that could potentially cover nearly thirty percent of global output. ${ }^{8}$ Other largescale agreements, such as the Trade in Services Agreement (TiSA) ${ }^{9}$, are currently being negotiated.

\footnotetext{
${ }^{2}$ https://www.law.ox.ac.uk/business-law-blog/blog/2017/11/european-commission-proposes-move-towardsmultilateral-investment (last visited 5 February 2018).

${ }^{3}$ Idem; see also http://eur-lex.europa.eu/legal-content/EN/TXT/?uri=COM:2017:493:FIN (last visited 5 February 2018)

${ }^{4}$ Legally, this petition took the form of a citizens' initiative. See https://www.euractiv.com/section/agriculturefood/news/anti-ttip-petition-signed-by-3-million-people/ (lastvisited 5 February 2018).

${ }^{5}$ https://www.euractiv.com/section/trade-society/news/german-judges-oppose-proposed-ttip-courts/ (last visited 5 February 2018).

${ }^{6}$ http://trade.ec.europa.eu/doclib/press/index.cfm?id=1468 (last visited 29 Sept 2017) http://trade.ec.europa.eu/doclib/docs/2013/november/tradoc 151918.pdf (last visited 23 January 2018)

${ }^{7}$ http://dfat.gov.au/trade/agreements/tpp/news/Pages/trans-pacific-partnership-ministerial-statement.aspx; https://www.herbertsmithfreehills.com/latest-thinking/a-comprehensive-and-progressive-agreement-fortrans-pacific-partnership (last visited 5 February 2018);

${ }^{8}$ https://www.reuters.com/article/us-japan-eu-trade/eu-japan-conclude-worlds-largest-free-tradeagreement-idUSKBN1E21BT; https://www.ft.com/content/b48e4f3a-dc0e-11e7-a039-c64b1c09b482 (last visited 5 February 2018).

${ }^{9}$ Involving twenty-three parties, one of these being the EU and thus representing (currently) 28 countries.
} 
The form of dispute settlements which will be adopted in these agreements is unsettled at the time of writing. ${ }^{10}$ More generally, the fate of any of these agreements is uncertain in a political world which is in flux-and which had expected neither the results of the Brexit referendum in the UK, nor the rise of the populist right in Europe, nor the election of Donald Trump in the USA. In particular, the long-term impact of President Trump's opposition to multilateral and comprehensive trade agreements remains far from clear. ${ }^{11}$ That said, with the recent confirmation that the UK has had initial discussions about joining the 'Pacific Rim' CPTPP after Brexit, ${ }^{12}$ it is clear is that this age of uncertainty around the management and governance of world trade appears set to continue for some time.

To keep things simple in this introduction, before our contributors highlight how complex things are, we could summarise the substantive (as opposed to dispute settlement) part of the debates by saying that the proponents of trade-plus agreements argue that the latter are bound to increase economic growth and prosperity, while opponents retort that these will seriously prejudice democratic decision-making, compromise social, welfare, and environmental standards, and open communities to predation by corporate power. Indeed, with the latter arguments increasingly heard, it maybe no exaggeration to say that the negotiation of trade-plus agreements has triggered a turning point in large scale civic engagement with international trade and investment law in Europe and elsewhere. ${ }^{13}$ Perhaps especially so, should populist and protectionist sentiments continue to rise around the world. ${ }^{14}$

\footnotetext{
${ }^{10}$ See the first references above at notes 7 and 8.

${ }^{11}$ In March 2017 the Financial Times reported on a battle over trade policy within the Trump administration between 'economic nationalists close to Donald Trump' and 'pro-trade moderates from Wall Street'. https://www.ft.com/content/badd42ce-05b8-11e7-ace0-1ce02ef0def9?mhq5j=e5 (last visited 3 October 2017).

${ }^{12}$ https://www.ft.com/content/73943036-efa9-11e7-b220-857e26d1aca4 (last visited 22 January 2018).

${ }_{13}$ This movement builds on earlier activism against neoliberal endeavours. See e.g. J Smith, 'Globalizing Resistance: The Battle of Seattle and the Future of Social Movements' 6 Mobilization: An International Quarterly (2001); C Summers, 'The Battle in Seattle: Free Trade, Labor Rights, and Societal Values' 22 U.Pa. Journal of International Economic Law (2001) 61; G Winslett, 'How Regulations Became the Crux of Trade Politics' 50 Journal of World Trade (2016) 47.

${ }^{14}$ Arguments as to why this might be so are many and varied but some aspects of the work of Anthony Giddens now seems prescient. See, for example, A Giddens Runaway World: How globalisation is re-shaping our lives, $2^{\text {nd }}$ ed. (Profile Books, 2002). More recently Pankaj Mishra has argued that we live in an 'age of anger' For a summary of his claims see $\mathrm{https}: / /$ www.theguardian.com/politics/2016/dec/08/welcome-age-angerbrexit-trump (last visited 5 February 2018).
} 
As such, the present period marks a significant-if not yet clear-moment in political and economic history which merits consideration and reflection. This special issue therefore offers six critiques each of which are differently contextualised through a variety of specific instances of historical, political or ideological relevance.

Setting the scene in the opening essay, Dembour and Stammers ask how one should understand the place of trade-plus agreements in European history. Are these agreements best seen as an expression of the EU institutions' neoliberal capture? Or, in contrast, do they represent a recent curbing of neoliberal excesses? Do they encompass a protectionist impulse rather than being just about free trade? These broad questions are explored through a discussion of the colonial roots of the foreigner's right to trade and ISDS, the social dimension of the European project, and the ascent of neoliberalism. The essay concludes by noting that, having achieved the status of 'common sense', neoliberalism was never going to just vanish. The ways in which neoliberalism became sedimented in law, technical practices and organisational cultures will continue to impact on international trade regimes, making it important to take heed of the warnings contained in the rest of the volume.

Ntina Tzouvala argues that there is no point in seeking a response to the negative impacts of trade-plus agreements in a further expansion and development of international law. Rather, the steady development of international law and institutions after 1990 should be seen as both the direct consequence and enduring precondition of the global hegemony of neoliberalism. In making her argument, Tzouvala revisits the work of key figures such as Wilhelm Roepke and Friedrich A. Hayek to demonstrate that the increased judicialisation and internationalisation of economic regulation is a vital feature of contemporary globalised neoliberalism. Tzouvala concludes that while most dedicated international trade and investment lawyers now acknowledge the short-comings of their respective regimes, a significant part of the discipline still operates under a suspension of disbelief in law's dark potential. 
Paul Gilbert argues that when European actors object to trade agreements by reference to a struggle between state and corporate interests over 'sovereignty', they miss important dimensions of what is at stake if they ignore the historical legacy of violent and extractive colonial encounters. He observes that when critiques of ISDS are couched in terms of sovereignty, critics often find themselves working within a binary of two types of sovereign power: a 'bad' dominative type and a 'good' emancipatory type. Sovereignty acquired by corporations figure as the former, 'bad', type, implying that the return of sovereignty to states (or communities) would function as a 'good', emancipatory form of sovereignty. Questioning this, Gilbert points out both that struggles for freedom through sovereignty can be dangerous, frequently recreating the injuries they seek to escape. Moreover, there may be an important temporal mismatch between critiques that appear to respond to historical, anti-colonial concerns about sovereignty, and the coordinates of our own contemporary circumstances.

Julia Rone's essay offers a timely reminder that international law does not emerge from a distinct international arena but is generally the result of competing and contradictory forces, including convoluted national politics. She examines the interplay between the Green and radical left positions, and the radical right opposition to the EUs trade-plus agreements, claiming that understanding the differences between different types of critiques is crucial to assessing proposed alternatives. Examining opposition to the tradeplus agreements in Germany, the UK, Italy and Bulgaria, she finds that, generally, it was left orientated parties and NGOs that were first to try to raise awareness of the risks of TTIP and CETA while radical right parties recognised the issue later and reframed many already established arguments in the language of national sovereignty and anti-free trade. Rone also examines how the debates on TTIP and CETA were linked to previously existing, but significantly different, national debates.

David Schneiderman warns that those who wish to negotiate trade agreements with the USA need to understand that their partner is determined to set the content of investment treaty standards. In theoretical terms, his essay examines the aspiration to universalise the particular in international investment law under what are usually labelled rules of 'global good governance' and 'universal' standards of justice. He does this by examining the 
debates in the US Congress when, in the summer of 2015, President Obama sought trade promotion authority (TPA) to complete negotiations toward TTIP and the TPP. Debates in Congress turned out to be far more contentious than the Democratic President and his Republican supporters anticipated. Both sides in this struggle were preoccupied with the question of whether US constitutional standards were mirrored in the content of international law. Schneiderman argues that through the study of these debates the inherent artifice and duplicity involved is revealed. Congressional debates turn out to be 'a site of struggle in which the prize is the universal.'

Anil Yilmaz-Vastardis' central argument is that the use of permanent international tribunals to improve access to justice for a class of privileged investors creates an unjustified 'justice bubble' which has inhibiting effects on improving local mechanisms for access to justice for the benefit of the wider society. Her essay focuses on the EU's attempt to render permanent the international investment arbitration model by adopting an investment court system in its investment agreements, and in its promotion, together with Canada, of a multilateral version of that court system. She warns that these initiatives are likely to entrench ever greater prioritisation of the commercial interests of the wealthiest few over wider societal interests at a global scale. She argues that the EU and its member states are now at a critical junction in terms of which path to choose for investor-state dispute settlement in the EU's new treaty framework and calls for a return to the prioritisation of local remedies.

Emerging from an academic workshop which took place at the University of Brighton in May 2016-at a time when TTIP was still very much on the cards and the Brexit vote one month away-it was the extent to which the EU institutions had been 'captured' by neoliberalism that was uppermost in the minds of most participants. But what unites these six essays and keeps them relevant is the over-arching conviction that the importance and complexity of the EU's engagement with the international trade regime needs to be fully grasped. The analysis must reach beyond the soundbites of recent political and media debates, however well informed, pertinent and important these may be. It is only through contextually informed critiques that the EU's approach to and involvement with trade-plus agreements may have a chance to be properly explained and understood. 
